\title{
Göç Kararında Kadın İradesinin Belirleyiciliği: Genç Kızların Köyden Kente Göç Etme Fırsatına Çevirmesi*
}

\author{
Hayrettin Şahin ${ }^{1}$ (])
}

\author{
Kemal Çiftyıldı ${ }^{2}$
}

\author{
Cemile Evkaya $^{3}$ (]
}

\section{Öz}

Kırdan kente göç türünü inceleyen bu çalışma uzun dönemli gözleme dayanarak hazırlanmıştır. Araştırmada, köyde ikamet ettiği sürece evlenemeyen genç erkekler ve evliliği kente göç etmede firsata çeviren genç kızlar ele alınmış ve her iki kesimin göç nedenleri ile göç sonrası sorunları irdelenmiştir. Kırdan kente göç edenlerin göç nedenleri arasında kentli olma, yoğun çalışma hayatından kurtulma, geleneksel aile yapısındaki kayın, görüm, elti, kaynana ve kaynatadan ayrı yaşayıp çekirdek aile kurma istekleri bulunmaktadır. Köyde kaldığı sürede evlenemeyen genç erkeklerin, kente göç edip iş bulunduklarında evlendikleri tespit edilmiştir. Köyde yaşamına devam eden yaşlılar ise, bir dönem geleneksel yapının zorluklarını (gelinlik, yaşam koşullarındaki zorluklar vb.) yaşamış olmanın yanı sıra bugün de modern dönemin sorunlarından olan yalnızlığı yaşamaktadırlar. Göçmen erkeklerin kentte karşılaştıkları sorunlar oldukça fazladır. Bunlardan başlıcaları; Iş bulmak, işe uyum sağlamak, çalışma yaşamında esnekliğin az olması, kent hayatına uyum sağlamak, barınma ve beslenme giderleridir. Göçmen kadınların ise komşuluk ilişkilerinin sınırlı olması, çalışma yaşamına katılamaması, kent hayatına uyum sağlayamaması gibi sorunları bulunmaktadır. Köyde geleneksel yapıda, ürettiğini tüketme ve günlük farklı işlerin yapma alışkanlığı modern sistemde yerini üretmediğini tüketmeye ve tek tip iş yapmaya bırakmıştı. Bu durum göç edenleri olumsuz yönde etkilemektedir.

\section{Anahtar Kelimeler}

Evlilik • Göç • Kırdan kente göç

* Bu çalışma, 2018 yılında Uluslararası Orta Asya Sempozyumu'nda tebliğ olarak sunulmuştur.

1 Sorumlu Yazar: Hayrettin Şahin, (Dr. Öğr. Üyesi), Ağrı İbrahim Çeçen Üniversitesi, İktisadi ve İdari Bilimler Fakültesi, Siyaset Bilimi ve Kamu Yönetimi Bölümü, Ağrı Türkiye. Eposta: sahinhayrettin@gmail.com

2 Kemal Çiftyıldız (Dr. Öğr. Üyesi), Bandırma Onyedi Eylül Üniversitesi, Manyas Meslek Yüksek Okulu, Mülkiyeti Koruma ve Güvenlik Bölümü, Balıkesir Türkiye. Eposta: kemalciftyildiz@gmail.com

3 Cemile Evkaya (Doktora Öğrencisi), Sakarya Üniversitesi, Siyasal Bilgiler Fakültesi, Çalışma Ekonomisi ve Endüstri İlişkileri Bölümü, Sakarya Türkiye. Eposta: cemileevkaya@gmail.com

Atıf: Şahin, H., Çiftyıldız, K. ve Evkaya, C. (2018). Göç kararında kadın iradesinin belirleyiciliği: Genç kızların evliliği köyden kente göç etme firsatına çevirmesi. Sosyal Siyaset Konferansları Dergisi, 75, 211-235. http://dx.doi.org/10.26650/jspc.2018.75.0014 


\title{
The Significance of Women's Will in the Decision on Internal Migration: Young Women's Preception of Marriage as a Path to Migrate from Countryside to City
}

Hayrettin Şahin ${ }^{1}$

\author{
Kemal Çiftyıldız ${ }^{2}$
}

\author{
Cemile Evkaya $^{3}$
}

\begin{abstract}
The study of the trend of urban - rural population shift is based on long-term observation. In the studies, cases of young men who could not marry as long as they lived in a village, and young women who transformed marriage into an opportunity to migrate to urban areas were addressed, showing both reasons for migration and the problems of an after migration life. The reasons for migration following are a wish to dismiss intense working life and the hope of creating a nuclear family, avoiding a traditional relationship with one's in-laws. It was determined that young men were not able to marry while living in the village and they could find job and marry very soon after moving to city. Elders who continue their lives in the village who also once experienced the difficulties of traditional structure (finding a bride, difficulties in living conditions etc.) also live in loneliness, which is a significant issue of our time. The traditional village structure of consuming what they produce and doing various types of work is replaced by readymade product consumption and monotonous work. This has negative effects on migrants. Migrant men face a lot of problems, in cities such as finding a job, adapting to work, a lack of flexibility in working life, adapting to urban life, and finding accommodation and adequate nutrition. Migrant women have difficulties with limited neighborhood relations, an inability to participate working life, and a failure to adapt to urban life.
\end{abstract}

\section{Keywords}

Marriage $\bullet$ Migration $\bullet$ Urban migration from rural areas

1 Corresponding author: Hayrettin Şahin, (Dr. Lecturer), Ağrı İbrahim Çeçen University, Faculty of Economics and Administrative Sciences, Department of Political Sciences and Public Administration, Agri, Turkey. Email: sahinhayrettin@ gmail.com

2 Kemal Çiftyıldız (Dr. Lecturer), Bandırma Onyedi Eylül Üniversitesi, Manyas Vocational High School, Department of Ownership Protection and Security, Balikesir Turkey. Email: kemalciftyildiz@gmail.com

3 Cemile Evkaya (Dr. Student), Sakarya University, Faculty of Political Sciences, Department of Labor Economics and Industrial Relations, Sakarya, Turkey. Email: cemileevkaya@gmail.com

To cite this article: Şahin, H., Çiftyıldız, K. and Evkaya, C. (2018). The significance of women's will in the decision on Internal migration: Young women's preception of marriage as a path to migrate from countryside to city. Sosyal Siyaset Konferansları Dergisi, 75, 211-235. http://dx.doi.org/10.26650/jspc.2018.75.0014 


\section{Extended Summary}

Human migration has a long history. It is well-known that hunting and herding tribes migrate in search of better pastures. Although the major causes of migration are disasters, wars and economic hardship, reasons for migrating still vary from person to person.

It can be said that two main revolutions in the history of mankind have influenced the course of migration. The first one is the agricultural revolution, realized by the use of animals in agricultural production, and the second one is the industrial revolution, realized by the use of machines in production. It is the concept of civilization that stands out in the agricultural revolution. The shift from nomadic to sedentary lifestyles is one of the important consequences of this revolution. On the other hand, the industrial revolution promoted modernization and the struggle between modern and traditional life began. This research is extremely important becasue it puts forth how changes in lifestyle differentiate and affect the experience of immigration.

Migrations are examined under three main headings. The first is the causes of migration, the second is the outcome of migration, and the third is the analysis of the migration processes. These subject can be subjected to different analyses in terms of preferred socio-economic models and political ideologies.

In this study, it was revealed how young women are determinative in their decision to migrate from the village to the city. Two important questions have been sought. One is the reason for pushing young women to migrate, and the other one is how young women persuade men to migrate. In addition to these two problems, postmigration encountered problems have been also mentioned. In this study the transition from traditional to modern society and village to urban life is examined. The conflicts between the traditional and the modern world and the change of people's priorities are also discussed.

The study is structured under three main headings. The first is the evolution of migrants in the village. İt has been divided into three separate divisions: the preRepublic migrations and the first years of the Republic, the years of dwellings and the periods of refugees. In the first period, which could be called a forced migration period, the First World War broke out, and the Republic was established. The most important migration event of this period was compulsory military service. In the 1950s, the process of going abroad (gurbet in Turkish) began. Gurbet is the temporary emigration of single men. These migrants sent their money home to provide for their families. Permanent immigration became more prevalent in the 1980s. After staying alone, gurbet men married and settled their families in foreign countries. Evenhough they visit their native country often, their real home is their new. 
In the second chapter, the causes of migration are examined. Factors igniting women's desire to migrate to the city are emphasized. These reasons are: continuity of the large family structure, work opportunties, the place of life and professional reputation problem, and the lure of the city.

In the last part, problems faced by immigrants who migrated from rural areas to cities and their solutions are explained in detail. These are: constantly doing the same job, having little autonomy in one's work, a lack of flexibility in working life, rent payment, the spending wages for food, limited play areas for children, difficulties in the participation of women to production, and changing of neighborhood relations. 


\section{Göç Kararında Kadın İradesinin Belirleyiciliği: Genç Kızların Evliliği Köyden Kente Göç Etme Fırsatına Çevirmesi}

Göç tanımlarının sayısı oldukça fazladır. Bu fazlalığının nedeni ise göç eden her bireyin farklı gerekçelerinin olmasından kaynaklanmaktadır. Göç, Türk Dil Kurumu tarafindan "Ekonomik, toplumsal, siyasi sebeplerle bireylerin veya toplulukların bir ülkeden başka bir ülkeye, bir yerleşim yerinden başka bir yerleşim yerine gitme işi, taşınması." olarak tanımlanmaktadır.

Modernleşme ile birlikte kırdan kente göçler önem kazanmıştır. İç göç açısından bakıldığında modernleşme öncesinde zorunlu göçler ön plandayken modernleşme ile birlikte gönüllü ve ekonomik göçler daha fazla görülmektedir. Özellikle kırdan kente göçler modernleşmenin önemli göstergelerinden birisini oluşturmaktadır.

$\mathrm{Bu}$ araştırma, gelenek ve modern yaşam tarzlarının farklılı̆̆ göçe bakmaktadır. Çünkü köylerde hala geleneksel hayat devam etmektedir. Öte yandan modern yaşam tarzı da kentlerde görülmektedir. Köyden kente göç eden kişi aynı zamanda gelenekten modern hayata da göç etmektedir. Geleneksel dönemin göçler açısından en önemli özelliği kimsenin iş arama, bulma ve işsiz kalma kaygıları bulunmamaktadır. Kişiler için önemli olan fizyolojik ihtiyaçların sağlanıp güvenlik ihtiyacının giderilmesidir. Oysa modern dönemin öncelikleri ve değerleri farklıdır. Bireylerin, fizyolojik ihtiyaçların yanı sıra kar peşinde koşma, kendini gerçekleştirme, kariyer yapma, iyi eğitim alma, haklardan yararlanma gibi öncelikleri bulunmaktadır.

Göç nedenleri, kişilere ve tarihe göre değişebilmektedir. Kişilerin ihtiyaçları sürekli değişmektedir. Maslow'un ihtiyaçlar hiyerarşisinde görüldüğü gibi birinci düzeyde karşılanması gereken ihtiyaçlar kolaylıkla karşılaşınca ikinci, üçüncü ve dördüncü düzeyler ön plana çıkmaktadır. Dolayısı ile insanlardaki istek ve ihtiyaç çeşitliliği göçe yansımakta ve göçün nedenleri de buna göre değişmektedir. Göç etme insanlığın varlığı ile ortaya çıktığı söylenmektedir. İlk çağda göç edenlerle modern dönemde göç edenler oldukça farklı nedenlere ve araçlara sahip bulunmaktadır.

$\mathrm{Bu}$ çalışma, köyden kente göç eden genç erkek ve kızların durumunu ele almaktadır. Bu dönemde, göç edenlerin, göç nedenleri arasında hangilerinin ön planda olduğunu ortaya koymaktadır. 


\section{Yöntem}

$\mathrm{Bu}$ çalışmayı diğerlerinden ayıran en büyük farklılık göç kararı alma sürecidir. Literatür taramasında, göç kararları arasında ekonomik ve zorunlu sebepler diyebileceğimiz iki büyük ana sebep karşımıza çıkmaktadır. Alt başliklar altında ise kentte yaşama, kent hizmetlerinden yararlanma, afetlerden kaçınma, meslek edinme, güvenli bölge bulma, ulaşımın gelişmesi, değerlerin değişimi, iş bulma vb. nedenler yer almaktadır. Ancak özellikle evlenebilmek için göç eden genç erkeklere göç literatüründe nadir olarak görülmektedir. $\mathrm{Bu}$ çalışmaya benzer eser Yılmaz tarafından 2009 yılında yazılmıştır. Eserin konusu benzer olsa da farklı yöre için yapılmıştır ve göç sonrası süreci kapsamamaktadır. Kente göç edemediği için evlenemeyen genç erkeklerin durumu, eserin kadınlara odaklanması nedeniyle gözden kaçmıştır. Diğer yandan Özgür ve Aydın tarafından 2011 yılında yazılan eserde kadınların evlendikleri erkeklerin evlerine göçmelerini konu almıştır. Batı bölgelerinde bazı erkeklerin kadınların evine göçtüğünü de ortaya koymuştur. Adı geçen eserde, modern-gelenek ayrımı ya da köy-kent ayrımı söz konusu değildir. Kadınerkek ve illerin farklılığı üzerinden bakılmaktadır. TÜİK verileri üzerinden mekânsal veri analizi yapılmıştır.

Araştırmanın konusu, köyde ikamet ettiği sürece evlenemeyen ancak göç edince evlenebilen genç erkeklerin ve evliliği fırsata çeviren kızların durumudur. Kızların neden köyde gelin olmak istemedikleri ve şehri tercih ettikleri etraflıca anlatılmıştır. Diğer yandan göç ettikten sonra karşılaşılan sorunlar üzerinde de durulmuştur.

Araştırmanın çalışma evrenini Erzurum'un Oltu ve Olur ilçelerinin köyleri oluşturmaktadır. Her köye ulaşmanın zorluğundan Oltu ve Olur ilçelerinden birer köy örneklem olarak ele alınmıştır. Bu köyler, Oltu İlçesi İnanmış Köyü ve Olur İlçesi Ilıkaynak Köyü’dür.

$\mathrm{Bu}$ araştırma, konuya yorumsamacı bir yaklaşımla kendi doğal ortamında yaklaşan nitel bir araştırmadır. Araştırmada, yorumlayıcı etkileşimcilik ile etnografyadan yararlanılmıştır. Yorumlayıcı yaklaşım, doğal gerçekliklerle toplumsal gerçekliklerin aynı yöntemle incelenemeyeceğini savunmaktadır. Doğal dünya insan etkileşiminden bağımsız olarak var olduğu halde, toplumsal dünya toplumsal ve kültürel ilişkilerle insanların anlamlı ve amaçlı eylemleri ile kurul- 
muş ve kurulmakta olduğunu varsaymaktadır. Diğer yandan etnografik araştırmalarda gerekli olan adımlar şunlardır: katılımcıların günlük yaşamlarını takip etme, araştırmanın amacından ayrılmadan, objektiflikten kopmadan bütünlüğü korunma, tanımlamalar yapma ve o ortamın normal elemanı gibi araştırılan kişilerin aralarına katılarak gerekli gördügü ayrıntıları toplamadır.

Veriler, 2011-2018 tarihleri arasında 7 yıllık bir süre içinde temel etnografik veri toplama tekniği olan katılımc1 gözlem yoluyla toplanmıştır. Gözlem ve alanla ilgili çeşitli kaynaklardan elde edilen bilgiler katılımcıların verdikleri anlamlar yoluyla mekanik olmayan bir tarzda yorumlanarak sosyal yapıya bağlanmıştır. 25 katılımcıyla söyleşi tarzında ve esnek akışta yapılan görüşmeler, alanla ilgili gözlem ve incelenen kaynaklar yoluyla edinilen kanaatler doğrultusunda yarı yapılandırılmış ve etkileşim içinde kendiliğinden ortaya çıkan yapılandırılmamış biçimde gerçekleşmiştir. Katılımcıların yaşam dünyaları hakkında ne düşündükleri ve hissettiklerini istedikleri şekilde ifade edebilmelerine olanak veren zeminin hazırlanmasına özen gösterilmiştir. Görüşme öncesi araştırmacı kimliği açıklanmış ancak araştırmacının alana kişisel ağlarla dâhil olması, kültürel atmosfere uyumlu davranış göstermesi ve görüşmelerde içtenlikli davranış sergilemesi araştırmacı kimliğinin öne çıkarmasını engellemiştir. Araştırma verileri genelde not tutma biçiminde kaydedilmiştir. Araştırılan kişilerin yanında olduğu sürece kişilerin davranışları değişmesin diye not tutma işlemi genelde akşam yalnız kalınca yapılmıştır. Araştırma notlarındaki önemli konular farklı kişiler üzerinde denenerek genelliği sorgulanmıştır.

Tablo 1

Katılımcilarının Özellikleri

\begin{tabular}{|c|c|c|c|c|c|}
\hline Kat1lımc1 Numarası & Cinsiyeti & Yaș1 & Medeni Hali & Cocuk Sayıs1 & Hanesinde Yașayanlar \\
\hline K1 & Kadın & 75 & Evli & 3 erkek $1 \mathrm{k} 1 \mathrm{z}$ & Eși \\
\hline K2 & Erkek & 81 & Evli & 1 erkek 2 kız & Eşi \\
\hline K3 & Kadın & 60 & Evli & 3 erkek 1 kız & Eşi \\
\hline K4 & Erkek & 68 & Evli & 1 erkek 1 kız & Eşi \\
\hline K5 & Erkek & 72 & Evli & 3 erkek 1 kız & Eşi \\
\hline K6 & Erkek & 77 & Evli & 2 erkek 3 kız & Eşi \\
\hline K7 & Kadın & 60 & Evli & 2 erkek 2 kız & Eşi \\
\hline K8 & Erkek & 79 & Evli & 2 erkek 3 kız & Eşi \\
\hline K9 & Erkek & 82 & Evli & 2 erkek & Eşi \\
\hline K10 & Erkek & 83 & Evli & 3 erkek 1 kız & Oğlu, gelini, torunları \\
\hline K11 & Kadın & 78 & Evli & 1 erkek 2 kız & Eşi \\
\hline K12 & Erkek & 68 & Evli & 2 erkek 2 kız & Eşi \\
\hline K13 & Erkek & 27 & Bekâr & & Anne-baba \\
\hline K14 & Erkek & 71 & Evli & 3 erkek & Eşi \\
\hline K15 & Kadın & 83 & Eşi ölmüş & $4 \mathrm{k} 1 \mathrm{z}$ & Yalnız \\
\hline K16 & Kadın & 25 & Bekâr & $\ldots$. & Anne-Baba \\
\hline K17 & Kadın & 25 & Bekâr & & Anne Baba \\
\hline
\end{tabular}




\begin{tabular}{llllll} 
Kat1lımc1 Numaras1 & Cinsiyet & Yaș & Evlilik Y1lı & Kardes Say1S1 & Hanesinde Yaşayanlar \\
\hline K18 & Kadın & 27 & 2015 & 3 erkek 3 k1z & Eși ve bir çocuk \\
\hline K19 & Erkek & 29 & 2012 & 1 erkek 4 k1z & Eși ve iki çocuk \\
\hline K20 & Kadın & 26 & 2015 & 2 erkek 3 k1z & Eși \\
\hline K21 & Erkek & 26 & 2017 & 4 erkek 1 k1z & Eși ve bir cocuk \\
\hline K22 & Erkek & 30 & 2018 & 2 erkek 3 k1z & Eși \\
\hline K23 & Kadın & 25 & 2018 & 3 erke 2 k1z & Eși \\
\hline K24 & Kadın & 28 & 2015 & 3 erkek 1 k1z & Eși ve bir çocuk \\
\hline K25 & Erkek & 35 & 2016 & 2 erkek 1 k1z & Eși ve bir çocuk \\
\hline
\end{tabular}

Çalışmanın dört ana başlı̆̆ bulunmaktadır. Bunlardan birincisi teorik çerçeve, ikincisi tarihi süreç, üçüncüsü gençlerin köy hayatından uzaklaşma sebepleri, dördüncüsü ise göç eden gençlerin kent yaşamında karşılaştıkları önemli sorunlardır.

\section{Teorik Çerçeve}

Göç konusu birçok bilim adamı tarafından çalışılmıştır. İlk kez 1885 ve 1889 yıllarında Georg Ravenstein'ın Londra'da göç üzerine sunduğu iki tebliğiyle gündeme gelmiştir. Sonraki süreçte giderek birçok bilim adamının yaptığı önemli katkılarla gelişme göstermiştir. Göç literatürünün gelişmesine katkı sağlayanlar içinde Todaro, Lee, Lewis, Katz, Stark, Castells, Massey vb. sayılabilir (Abadan-Unat, 2006:19-41).

Göç türleri incelendiğinde beş önemli tasnif dikkat çekmektedir. Bu tasnife göre ülke sınırı bakımından iç-dış göç, göçe kara verme bakımından gönüllü-zorunlu göç, süresi bakımından mevsimsel-sürekli, akım yönüne göre kırkent ve göç edenlerin niteliği bakımından mavi-beyaz yakalı olarak ele alınabilmektedir (Çelik, 2012:9-10; Hocaoğlu, 2011:81-85). Araştırmanın, bu göç tasniflerinden hangisi içerisinde ele alınması gerektiğini çok kesin çizgilerle ifade etmek oldukça zordur. Evliliğin önemli bir ihtiyaç olarak ele alınması durumunda zorunlu, ihtiyaç olarak düşünülmez ise gönüllü göç olarak sınıflandırılabilecektir. Sınırı bakımından iç göç, süresi bakımından sürekli, akım yönünden kırdan kente doğru ve göç edenlerin modern dünyadaki niteliği bakımından mavi yakalı türünde olduğu söylenebilir.

19. ve 20. yy. ortaya çıkan birçok göç kuramı mevcuttur. Ekonomik göç kuramları (fayda maliyet yaklaşımı, seçkinlik yaklaşımı, itme-çekme yaklaşımı), tarihsel-yapısalcı (merkez-çevre) göç kuramı, ağ ilişkileri (network) göç kuramı, göç sistemleri kuramı, ikiye bölünmüş (segmented) emek piyasası kuramı, kuramsal kuram, kümülatif nedensellik kuramlarının kuramlar 
arasında ön plana çıktığı söylenmektedir (Abadan-Unat, 2006: 19-41; Çelik, 2005;167-184; Castles ve Miller, 2008: 36-39; Çağlayan, 2006: 67-90; Gezgin, 1991:37-38; Vergin, 2010:187-193). Araştırma, itme çekem kuramına göre yapılandırılamamıştır. Zira ekonomi kadar diğer etkenlerde bulunmaktadır. Aile ilişkileri, toplumsal baskı, iş yoğunluğu göç nedenleri arasında ön plandadır. Tarihsel-yapısalcı yaklaşım daha çok merkez ve periferi üzerine odaklanmaktadır. Bu çalışma göç alan ve veren mekan bakımından zaten periferi içerisinde değerlendirilmektedir. Ağ ilişkileri kuramı yalnız başına durumu açıklayamaz. Çünkü göç kararı, ağ ilişkileri kuramında kısmen önem arz etmektedir. A ğ ilişkileri daha çok göç kararından sonra devreye girmektedir. Ancak karar vermede kısmen etkili olduğu söylenmektedir. Göç sistemleri kuramı ülkeler arası göçler için kullanılmaktadır. Diğer kuramların da kendine has geneli kapsamayan özellikleri mevcuttur. Dolayısı ile herhangi bir kuram etrafında bu çalışmayı şekillendirmek doğru olarak görülmemiştir.

Göçün bu derece önemli olmasının sanayileşme ve modernleşme ile alakası oldukça fazladır. Çünkü dünya nüfusunun çoğu geleneksel dönemde köylerde yaşarken modern dönemde kentlere doğru hareket etmiştir.

Modernleşme ile aile yapıları değişime uğramıştır. Büyük aileden çekirdek aileye dönüş hızlanmıştır. Bu durumun daha ileriki safhası ise modernleşen toplumlarda görülen evsiz (homeless) tipi yaşamdır. Tek başına yaşamanın yaygınlaşmasıyla gelenekte önemli olan; "baba ocağı ve ana kucağı” olgusu değerini yitirmektedir.

Göç genelde erkeğin iradesinde gerçekleşmektedir. Erkeğin aile içerisinde ilk öne sürülebilir olması bunda başat etkendir. Birçok çalışmada erkeğin karar almada kendi başına karar verdiği üzerinde durulmaktadır. Yapılan çalışmada, erkeğin kararlarda etkili olduğu görüşünün (Şencan, 2013:19-26) aksine riske ilk sürülen kişi olmasından kaynaklı olduğu görülmektedir. Araştırma bölgesinde son dönemlerde göçün karar vericileri ve sürecin yöneticilerinin kadınlar olduğu gözlemlenmiştir. Kadının haneye hâkimiyeti gittikçe artmaktadır. Çocuklarını ve eşini kente yönlendirerek modern hayata doğru yol almak istediğini göstermektedir. 


\section{Araştırma Sahası Genel Bilgileri}

Evreni oluşturan araştırma sahasında yani Oltu ve Olur ilçelerinde toplam 37.399 kişi yaşamaktadır. Araştırmanın örneklemini oluşturan sahada ise, İnanmış Köyü’nde 94 kişi, Ilıkaynak Köyü'nde 98 kişi ikamet etmektedir. Hanede yaşayanların sayıları genelde iki ve üçtür. İki kişi yaşayanlar genelde karı-kocadır. Üç kişilik hanelerde ise genelde anne-baba ve evlenmemiş bir çocuk bulunur.

Tablo 2:

Araştırma Sahası Nüfus Bilgileri

\begin{tabular}{|c|c|c|c|c|}
\hline Y1l & Yerleşim Yerinin Ad1 & Nüfus & Yerleşim Yerinin Adı & Nüfus \\
\hline \multirow{2}{*}{2007} & Ilıkaynak & 110 & İnanmış & 170 \\
\hline & Olur & 2429 & Oltu & 20162 \\
\hline \multirow{2}{*}{2008} & Ilıkaynak & 117 & İnanmış & 166 \\
\hline & Olur & 2177 & Oltu & 20305 \\
\hline \multirow{2}{*}{2009} & Ilıkaynak & 118 & İnanmış & 175 \\
\hline & Olur & 2141 & Oltu & 19729 \\
\hline \multirow{2}{*}{2010} & Ilıkaynak & 121 & İnanmış & 162 \\
\hline & Olur & 2225 & Oltu & 19969 \\
\hline \multirow{2}{*}{2011} & Ilıkaynak & 117 & İnanmış & 154 \\
\hline & Olur & 2193 & Oltu & 21109 \\
\hline \multirow{2}{*}{2012} & Ilıkaynak & 122 & İnanmış & 135 \\
\hline & Olur & 2157 & Oltu & 22127 \\
\hline \multirow{2}{*}{$2013 * *$} & Ilıkaynak & 108 & İnanmış & 127 \\
\hline & Olur & 7181 & Oltu & 31346 \\
\hline \multirow{2}{*}{2014} & Ilıkaynak & 108 & İnanmış & 104 \\
\hline & Olur & 7082 & Oltu & 31424 \\
\hline \multirow{2}{*}{2015} & Ilıkaynak & 105 & İnanmış & 108 \\
\hline & Olur & 6708 & Oltu & 31087 \\
\hline \multirow{2}{*}{2016} & Ilıkaynak & 92 & İnanmış & 100 \\
\hline & Olur & 6510 & Oltu & 31056 \\
\hline \multirow{2}{*}{2017} & Ilıkaynak & 98 & İnanmış & 94 \\
\hline & Olur & 6398 & Oltu & 31001 \\
\hline
\end{tabular}

*TÜİK, ADNKS, https://biruni.tuik.gov.tr/medas/?kn=95\&locale=tr

**2013 ve sonraki yılların nüfus yapısı Büyükşsehir Kanunu'ndan dolayı farklılaşmaktadır. Köyler mahalle statüsüne geçirilmiştir. İlçelerin nüfusu merkezin yanı sıra mahalleri (köyleri) de kapsamaktadır.

Tabloya göre her iki köyde ve her iki ilçede nüfusun azaldığı görülmektedir. Köyden en yakın kentlere göç etmenin yanı sıra uzak kentlere de göç edilmektedir. Araştırmanın yapıldığı yöreden İstanbul, İzmir, Bursa, Ankara'ya göçlerin olduğu bilinmektedir. Bazı göçler direkt (köyden-metropole) olduğu gibi bazı göçlerin kademeli olduğundan bahsedilebilir. Köyden yakın kente ve yakın kentten büyük kentlere doğru kademeli olarak gerçekleşmektedir. 
Araştırma yapılan iki köyde kişilerin gelirleri, tarım, hayvancılık ve emekli maaşlarına dayanmaktadır. Ayrıca bakım ve yaşlılık yardımları alanlar da bulunmaktadir.

İki köyde, süt ve süt mamulleri, et ve et mamulleri, patates, mısır, fasulye, buğday, arpa, yonca, korunga, yulaf üretilmektedir. Bunların birçoğunu kendileri tüketirken bazılarını dışarıya satmaktadırlar. Ilıkaynak Köyü’nde büyükbaş hayvan sayıları olukça fazladır. Geçimleri genelde büyükbaş hayvana dayanmaktadır. İnanmış Köyü'nde ise kısmen büyükbaş hayvanı, kısmen de patates üretimi ekonomide önemli yere sahiptir.

Mimari yapı açısından her iki köy de birbirine benzemektedir. Genelde yapılar tek katlıdır. Bazı evler çift katlıdır. Çok nadir olsa da çok katlı binalara rastlanmaktadır. Evlerde su ve kanalizasyon altyapıları bulunmaktadır.

\section{Bulgular}

Araştırma bulguları üç ana bölüme ayrılarak hazırlanmıştır. Birinci bölümde göçün tarihi süreci ele alınmıştır. İkinci bölümde gençlerin köy yaşamından neden uzaklaşıp kent hayatını tercih ettikleri üzerinde durulmuştur. Son bölümde ise göç edenlerin kentte karşılaştıkları sorunlar ortaya konulmuştur.

Araştırmanın Yapıldığı Yörede Göçün Tarihi Süreci ve Geçirdiği Evreler

Çalışmada, Cumhuriyet dönemi ele alınmış, bu dönem içerisinde de son dönem üzerinde durulmuştur. Araştırmanın yapıldığı yöre için göç dönemleri üçe ayrılmıştır. Bunlar: Zorunlu göçler dönemi, belirli süreli göçler (gurbet ) dönemi ve süresiz aile göçleri (muhacir gitme) dönemidir. Bu üç dönemin tamamlanması ile köylerdeki insanların kentlere göç etmesi neredeyse tamamlanmış ve kırdan kente göçlerin evrimi yerini kentten kıra bırakmıştır. Zorunlu göçler dönemi, 1877- 1950'li yıllar aras1; belirli süreli göçler dönemi 1950-1980 yılları arası ve süresiz aile göçleri dönemi 1980 ve sonrası yılları kapsamaktadır.

Yeni dönemde köye dönüşler ağırlık kazanmıştır. Köylerde az katlı, bahçeli modern evlerin sayısı azımsanmayacak kadar çoktur. Bununla birlikte belirli dönemlerini köyde geçirenlerin sayısı da oldukça artmıştır. Bu durum bize ileriki yıllarda kentlerden köylere doğru önemli bir göç akımının olacağının ipuçlarını vermektedir. 


\section{Zorunlu Göçler Dönemi}

Bu dönem 1878 yılı Osmanlı-Rus savaşı ile başlayıp 1950 yılında tamamlanmaktadır. Bu dönemde, göçler daha çok savaş ve iç karışıklıklar nedeni ile olmuştur.

$\mathrm{Bu}$ yörede göç kelimesinin köç kelimesi ile yakın ilişkisi tespit edilmiştir. Köç eşya anlamındadır. Eşya ve malını toplayıp gitme anlamını da içerir. "Köçünü topladı" (eşyasını topladı gitmeye hazır) deyimi çok kullanılmaktadır. Köç toplayıp gitmek daha çok zorunluluğun bir belirtisidir. Afetlerde, savaşlarda ve çok olumsuz sayılabilecek durumlarda köç toplanıp gidilir. Aynı zamanda kızların, evlenerek evinden çıkıp kocasının evine gitmesini anlatmak için de kullanılır (köç etti denilir).

Zorunlu göç dönemi, daha çok Cumhuriyet öncesi dönemi ilgilendirmekle birlikte, Cumhuriyet döneminde de zorunlu göçle ilgili birkaç önemli gelişme olduğu söylenmektedir. Çünkü Osmanlı Devleti’nin yıkılması ve Türkiye Cumhuriyeti'nin kurulması esnasında bu yörede göçle ilgili birçok olay cereyan etmiştir.

Oltu ve Olur ilçelerinde bugün yaşayanların birçoğunu Ahıska'dan göç edenler oluşturmaktadır. 1800'lü yıllarda önemli sayıda Rusya'dan göçmenler gelmiştir. 1877-1878 savaşı sonucunda Oltu'nun Kaleboğazı Köyü’nden Osmanlı-Rus sınırının çizilmesi ile birlikte Kaleboğazı'nın doğusunda kalanların bir kısmı ikinci kez göç etmişlerdir. Daha sonra, Birinci Dünya Savaşı olmuş, bunun neticesinde iki kez göç etmek zorunda kalanlar üçüncü kez göç etmişlerdir. Bu kez, Yozgat, Tokat, Kahramanmaraş gibi illere kadar gitmişlerdir. Bu illere göç edenlerin bir kısmı gittikleri yerlerde kalırken bir kısmı da Rusya'nın geri çekilmesi ile Oltu ve Olur ilçelerindeki köylerine geri dönmüştür (K3, K4, K7).

Oltu ve Olur'da yaşayan Rusya yanlılarının bir kısmı Güney'e göç ettirilirken bir kısmı da Erivan'a doğru göç etmiştir (Karpat, 2010). Modern toplumların ulus devlet inşası bazı toplumlarda dil üzerine bazı toplumlarda din üzerine kurgulandığı söylenebilir. Her iki durumda da kurucu anlayışın dışarda kalanlar genelde göçe zorlanmaktadır.

Cumhuriyet'in kurulması ile Oltu ve Olur ilçelerinin köylerinde önemli bir göç hareketi görülmemektedir. 1930’lu yıllarda Oltu İlçesi’nden Hınıs 
İlçesi'ne göç teşvik edilmiştir. Diğer önemli bir olay da 1930'lu yılların sonunda Tunceli'den zorunlu iskâna tabi tutulanların bir kısmının Oltu'nun köylerine yerleştirilmeleridir (K7, K12).

Cumhuriyetin ilk yıllarında köyde yaşayanların göç tecrübeleri en fazla askeri görevle alakalıdır. Askeri görev için orduya katılanlar durumuna göre üç ile yedi yıl arasında görev yaptıkları nakledilmektedir. Askeri görev sırasında bir yandan farklı kültürlerde insanlarla karşılaşırken bir yandan da meslek sahibi olabilmektedirler. Modern yaşamla ilk önemli temasları askerlik görevi nedeni ile olduğu söylenebilir.

\section{Belirli Süreli Göçler Dönemi}

Osmanlı Dönemi'nde başlayan modernleşme hareketleri Cumhuriyet Dönemi'nde de devam etmiştir. Araştırmanın yapıldığı yöredeki köylülerin modern hayata katılması ise Cumhuriyet' in kurulmasından sonraki yıllarına denk gelmektedir.

Türkiye'de 1950'li yıllara gelindiğinde sanayileşme ve modernleşmenin belirli bir ivme kazanması ile köyden kente göç hareketleri artarak devam etmiştir. $\mathrm{Bu}$ dönemde Oltu ve Olur ilçelerinin köylerinde başlayan göç hareketinin türü gurbettir. Geniş ailede ailenin genç fertlerinden bazıları geçici süreliğine "ek gelir ihtiyacı" için başka yerlerde gidip çalışmakta ve getirmiş olduğu sermaye geniş ailenin ihtiyaçlarını karşılamak için harcanmaktadır. Buna "gurbete gitme" denilmektedir. Araştırmanın yapıldığı yörede, Özellikle 1960'l1, 1970'li ve kısmen 1980'li yıllarda göçler bu türdendir. Bu yıllar, aynı zamanda yurt dışı göçlerinin de başladığı yıllardır. Özellikle Avrupa ülkelerine geçici göçler olmuştur. Aynı zamanda, Libya, Arabistan ve Irak'a dış göç akımı görülmektedir (K1, K5).

1923-1950'li yıllar tepki yılları olarak görülmektedir. Bu yörede yöneticilerin katı laik tutumu (kamu yetkililerinden korkan kişilerin, Arap harfiyle yazılmış kitapları hayvan gübreleri içerisine ve başörtülerini toprağa gömmesi) devlet ile millet arasında gerginliğe sebebiyet vermiştir. Menderes'in iktidara gelmesi ile Arap alfabesinin kullanımına getirilen kısıtlamaların önemini yitirmesi bu yörede sevinçle karşılanmış ve devlet millet birlikteliğine katkı sağlamıştır (K5, K8, K6). 
$\mathrm{Bu}$ dönemde okullaşma oranlarının artması, askere gidenlerin meslek kazanmaları ve ağ ilişkisi kurmaları ve gurbete gidenlerin modern yapıları ve araçları görmeleri toplumsal değişime önemli etki etmiştir.

Üç koldan gelen değişim aileleri her ne kadar etkilese de kentte tutunmanın zorluğu, geleneksel yapının korunaklı zırhı (din, dil, kültür, töre vb.) modern dünyaya adapte olmaktaki süreci geciktirmiş olabilir. Bu değişimde kadının rolünün kısıtlı olması da diğer önemli bir neden olarak görülebilir.

\section{Süresiz Aile Göçleri Dönemi}

Göç biçimi 1980'li ve 1990'l1 y1llarda süresiz aile göçüne (ailesi ile birlikte sürekli kalmak amacı ile göç etme) şekline dönüşmüştür. Süresiz göç edenler gittikleri yerde yerleşmeyi planlayan kişilerdir. 1980'li ve 1990'lı y1llardaki göçlerin çoğu bu yöndedir. Aynı dönemde genç kızların şehirde yaşayanları tercih ederek kentlere göç ettikleri de görülmektedir. Dış göçlerde Avrupa'ya olan göçler azalmış ve Arap ülkeleri ile SSCB'den ayrılan ülkelere inşaat sektöründe çalışmak üzere birçok kişi göç etmiştir. Bu dönemin son yıllarında ise kentten köye dönüşler önem kazanmıştır.

Avrupa'ya gurbetçi olarak gidip sonra orada kalmayı arzu edenler önce kendi ailelerini oraya götürmüştür. Aile içerisindeki çocukları genelde Türkiye'deki akraba ve tanıdıklarla evlendirmişlerdir. Bu suretle hem kendi kültüründen kişi ile yeni aile kurulmuş olmaktadır hem de Türkiye'deki ailelere iş ve kazanç yolu açılmış olmaktadır. Bu durumdan başlangıçta her iki taraf ta memnunken sonraki süreçte durum değişmiştir. Çünkü Avrupa'da yetişen gençle Türkiye'de yetişen genç arasında önemli kültürel farklılıklar bulunmaktadır. Bu durum halk ozanları (Reyhani, Ruhani, Nusret, Çobanoğlu, Ergani vb.) tarafindan sıkça işlenmektedir. Son dönemde, yurt dışından evlenen kimseye rastlanmamıştır. Yurt dışından evlenenlerin birkaçının boşanması, birkaçının şiddetli geçimsizliği ve vize alımlarının zorlaşması yurt dışında evlenmeye olan ilgiyi azaltmıştır (K7, K12, K10).

Genç erkekler sürekli göç etmeden önce genelde geçici olarak göç etmektedir. Yani gurbete gidip para kazanmaktadır. Kendine sürekli çalışacağı bir iş bulmaktadır. İkinci aşamada evli ise ailesini yanına almakta ya da evli değilse evlenip eşi ile birlikte göç etmektedirler. Böylece köyden kente göç etmenin yanı sıra geleneksel aile yapısı da yerini çekirdek aile yapısına bırakmaktadır. 
Köylerden kentlere göç sırasında ağ ilişkilerinin sıklıkla kullanıldığına tanık olunmuştur. Gurbet diye adlandırılan ve ailenin birkaç erkek üyesinin katıldığ 1 göçlerde ilk giden yanına diğer akraba ve hemşerilerini de almakta ve birbirlerine iş bulmada yardımcı olmaktadırlar. Aynı zamanda birbirlerinin beslenmesine ve barınmasına da katkı sağlamaktadırlar.

Köylülerin kısa sürede kentlere göç etmesinin nedeni ile ilgili birkaç önemli tespit yapılmıştır. Bunlardan birincisi, asker ocağının toplumun modernleşmesi için yaptığı çalışmalardır. Bu ocak sayesinde birçok değişim olmuştur ancak genel anlamda toplumun modernleşmesinden bahsedilemez. İkincisi, okullaşma oranlarının artması ve okul mezunlarının önemli görülen görevlere gelerek refah ve saygınlık kazanmalarıdır. Her iki durumda da önemli bir değişimden bahsedilemez. Çünkü her iki durumdan da yararlananlar genelde erkekler olmaktadır. Bu yörede asıl aileyi bir arada tutan kadındır ve kadın ailenin kararlarında baş etkendir. Üçüncüsü kadının modern dünyayla tanışmasıdır. Kadının modern dünya ile tanışması televizyonlarla olmuştur. Dördüncüsü, toplumla yöneticilerin arasının iyileştirilmesi ve dinde reform niteliğinde değişimleri savunan cemaatlerin öne çıkarılmasıdır.

Asker ocakları kişilere meslek edinme, farklı toplumlardan kişilerle beraber yaşama, ast-üst ilişkilerini öğrenme, Latin harfleri ile okuma-yazma öğretme, merkezi sisteme adapte olma vb. şekilde modern devletlerin uyguladığı birçok aracı uygulamıştır. Bu uygulayış sadece erkeklerle sınırlı olduğu için güdük kalmıştır denilebilir. Çünkü bu yörede gelenekselden moderne geçiş erkek öncülüğünü gerektirse de asıl olan kadındır. Kadının nesil ve aile üzerindeki etkisi oldukça fazladır.

Bir yandan yöneticilerin toplumla olan ilişkilerindeki yumuşamalar, diğer yandan köydekilerin modern yaşama aşinalıklarının artışı ve okula gidenlerin önemli görülen meslekleri elde etmeleri ve bunun neticesinde refah düzeylerini artırmaları ve toplumda saygınlık kazanmaları okulun önemini artırmıştır. Bir yandan her çocuk okula gönderilirken diğer yandan da çocukların daha iyi okullarda öğrenim görebilmeleri için öğrencilerin aileleri kente göç etmiştir.

Araştırmanın yapıldığı iki köyde de öğrenci yokluğundan okulları kapatılmıştır. Köylerde bulunan birkaç öğrenci ise taşımalı sistemle eğitim-öğretimine devam etmektedir. İnanmış Köyü’nün öğrencileri Orcuk Köyü’ndeki okulda, Ilıkaynak Köyü’nün öğrencileri ise Olur ilçe merkezindeki bir okulda eğitim öğretimine devam etmektedir. 
1980'li yıllarda televizyon bu yörenin köylerinde yaygınlaşmaya başlamıştır. Önce zenginler ve muhtarlarla gelen değişim sonrasında herkes tarafından kabul görmüştür. Modern yapının misyonerleri her evde yerini almıştır. Artık geleneğin iyi olduğunu kimse söyleyememektedir. Herkes modern yapının cazibesi içerisinde bakış açısını değiştirmiştir. Aile içerisindeki itaat ve görevler yerini modern yaşama özenti ve birey olma isteğine bırakmıştır.

1950’li yıllarda cemaatler kendilerini göstermeye başlamıştır. Önceleri tarikat, tekke, zaviye şeklinde görülen örgütlenmeler sonraları cemaat ve cemiyet şekline dönüşmüşlerdir (Kara, 2013). Bunlar içerisinde geleneksel yap1sını devam ettirenler olduğu gibi modern yapıya uyum sağlamak için seküler hale gelenler de bulunmaktadır. Bu cemaatlerin en önemli temsilcisi, modern yaşamı usul değil esas olarak ele alan, kutsal olanı bilimle açıklayan, "siyasetin şeytan işi olduğu varsayımı" "ile din ve devlet işlerinin ayrılmasına öncü olan Nurculuk hareketidir.

Bazı hanelerde sadece yaşlılar bulunmaktadır. Yaşlıların ölmesi ile bir taraftan haneler kapanmakta diğer yandan köyün kadim gelenekleri üzerine kurulu olan köy yaşamı son bulmaktadır. Kadim gelenekle yaşamını sürdürenlerin yerine, modern yaşama eklemlenmiş kişiler köylere sürekli akın etmektedir. Atasının yaşadığı yere tekrar dönen emekli kişiler, yazlık yaparak ömrünün bir kısmın burada geçirmektedir. Bu kişilerin yaşam biçimi geleneksel yapıdan ziyade modern yapı ile daha uyumlu görünmektedir.

Şehirde emekli olup yazı köyde geçirenler tarımla uğraşmaktadır. Ancak tarımı kazanç kapısı olarak değil uğraş olarak ele almaktadırlar. Toprağa ve hayvanlara bağımlılıkları yoktur. Sabah erken kalkıp süt sağmak, hayvanları yemlemek ya da tarla sulamak zorunda değildirler. Çoğu birkaç ağaç ve sebze dikip şebeke suyu ile sulama yapmakta, küçük bir bölümü ise küçük seralar yaparak kendine yetecek kadar sebze yetiştirmektedir.

Özellikle 2000'li yıllar ile birlikte köy içerisinde evlenenlerin oranı giderek düşmüştür. Araştırmanın yapıldığı iki köyde de köyde ikamet eden genç erkek ve kızların birbiri ile evlendiğine 2015'ten 2018 yılına kadar neredeyse hiç rastlanmamıştır. Köyde yaşayan genç erkekler kentte yaşayan bir kızla da evlenememektedir. Dolayısı ile köyde kaldığg sürece ne köyden ne de kentten bir eş adayı ile evlenmesi olanaksız gibi görünmektedir. Bir taraftan toplumun kente 
göç ettirme baskısı diğer yandan kızların köydeki genç erkeklerle evlenmemeleri onları göçe zorlamaktadır.

Yukarıda sayılan nedenler köylülerin göç etmesinde önemli bir etkene sahip olduğu düşünülebilir. Ama bunun yanı sıra toprakların miras ile bölünerek azalması, makine kullanılarak insan işgücüne ihtiyacın azalması, gelir düşüklüğü (Başel, 2007, s. 521-524), köyde makine kullanılmadan üretilen ürünlerin makine kullanılarak büyük şirketler tarafindan üretilen ürünlerden daha düşük fiyatta olması vb. nedenler de göçün köylerden kentlere doğru akışını etkilediği bilinmektedir.

2011-2018 yılları arasında, köylerde yukarıda sayılan göç nedenlerinin dışında başka nedenlerin oluştuğu tespit edilmiştir. Özellikle genç kızların köyden kente neden gittikleri aşağıda ayrıntılı şekilde yer verilmiştir.

Köy Hayatından Uzaklaşma Nedenleri ve Kent Hayatının Cazibesi

Köy hayatından uzaklaşma nedenleri oldukça fazladır ve bu nedenler sürekli değişime uğramaktadır. Bir dönem çok etkili olan bir neden başka bir dönemde etkisini yitirebilmektedir. Gözlemler neticesinde, bu dönemde, köyden uzaklaşma nedenleri olarak şunlar tespit edilmiştir:

a-Büyük aile kurumunun kısmen devam etmesi

b-Gözetlenme

c-İş yoğunluğu

d-Yaşam yeri ve mesleki itibar sorunu

e-Kentin cazibesinin yüksek olmas1

\section{Büyük Aile Kurumunun Kısmen Devam Etmesi}

Köyde evlilik yapmaları durumunda geniş aile içerisinde yaşama ihtimalini göz önünde bulunduran genç kızlar, köyde yaşayan genç erkeklerle evlenme isteğini geri çevirmektedirler. Çünkü geniş aile içerisinde eveleneceği kişinin kardeşleri, anne-babası, eltisi ile geçinebilme riski kızları düşünmeye sevk etmektedir. Kentte yaşayan elti, görüm, kayın, torun vb. anne baba ziyaretlerine köye geldiğinde, gelenlere hizmet etmek evdeki gelinin görevi olarak 
görülmektedir. Beklentileri karşılayamamanın baskısı onları geçimsizliğe itebilmektedir. Bu durumla karşılaşmamak için kente göç etmiş kişi ile evlenmek genç kızlara daha cazip görünmektedir (K18, K20, K3).

Bireyselliğin ön plana çıktığı modern zamanda bir arada yaşamak oldukça zor görünmektedir. Çekirdek ailede bile kişilerin birbirine tahammülü oldukça sınırlıdır. Son yıllarda gerçekleşen boşanma oranlarının artması buna örnek olarak gösterilebilir. Diğer yandan modernleşmiş batı toplumlarında birey olarak yaşamanın yaygınlaşması ve evsiz olarak yaşayanların sayısında artış olmasının bunun göstergesi olduğu söylenebilir.

\section{Gözetlenme}

Gençlerin çoğu gözetlenmeden rahatsız olmaktadır. Evler az katlı ve sokağa baktığı için kişilerin komşularını ve yoldan geçenleri görmesi olağandır. Mahalleden kimin ne yaptığı bilinmektedir. Geleneksel yöntemle büyüyen çocuklar için gözetlenme normal karşılanmaktadır. Ama televizyonda farklı kültürle karşılaşması, okula gitmesi vb. nedenlerle davranışlarında farklılıklar görülebilmesi ile durum değişmektedir. Bu farklılıkların köylüler, komşular ve aileler tarafından sürekli sorulması kişilerde sürekli gözetleniyormuş hissi oluşturmaktadır. Kişiler işleri olmadıkça ya da geçerli bir nedenleri bulunmadıkça dışarı çıkmazlar. Bu durum kadınlarda daha bariz görülmektedir. Kente göç ederek bu durumdan kurtulmak istemektedirler (K24, K18, K23, K19).

\section{İş Yoğunluğu}

Kızların köydeki genç erkekleri tercih etmemelerinin önündeki diğer önemli neden ise iş yoğunluğunun kentteki akranlarına göre çok fazla olmasıdır. Köyün geleneksel hayatını devam ettirenler sabah erken kalkıp hayvancılık ve tarım işleri ile meşgul olmaktadırlar. İnek sağımı, süt mamullerinin üretimi, hayvanların bakımı, çapa yapma, ot biçme, tahıl hasadı, yemek pişirme, ekmek pişirme, çamaşır yıkama, çocuk bakımı vb. işler kızların gözünü oldukça korkutmaktadır. Diğer yandan kentte yaşayan genç kızların bu işlerin çok azını yapmaları onların kolayı seçmesine sebebiyet vermektedir (K22, K18, K21, K19, K25). 


\section{Yaşam Yeri ve Mesleki İtibar Sorunu}

Köyde yaşayıp orada çalışanlar kendi mesleklerini ve yaşam yerlerini kentte yaşayanlara göre daha düşük seviyede görme eğilimindedirler. Kendi yaşamlarını hor görme eğilimi onların bir an önce kente göç etmelerinde önemli bir etken olarak görülmektedir. Köyde yaşayan yaşlısı-genci, kadını-erkeği velhas1l hepsi kentte yaşamı bir amaç haline getirmektedir (K1, K3, K6, K11, K20).

Tarım ve hayvancılıkla uğraşmak da olumsuz görülen bir durumdur. Göç eden erkeklerin birçoğunun köyde yapmış olduğu işler, şehirde yaptıklarından daha kolay olmasına rağmen şehirdeki işleri tercih etmektedirler (K19, K21, K22, K25).

Kente göç edip çekirdek aile biçiminde yaşayanlar, tatillerde köye gelip akraba ziyaretinde bulunmakta, piknik yapmakta ve eğlenmektedirler. $\mathrm{Bu}$ farklı yaşam biçimi köyde yaşayan birçok kişinin bu yaşam biçimi ile yaşama isteklerini artırmaktadır. Gerek kentsel yaşam biçiminin gerekse de kentteki mesleklerin itibarının köyde yaşayanlar tarafından kendi yaşam yerlerinden ve mesleklerinden daha yüksek görülmesi önemli bir göç nedeni olarak karşımıza çıkmaktadır.

Köylülerin ürettiği ürünlerin kentte üretilenlerden itibari olarak daha düşük olduğu yönünde birçok örneğe rastlanmıştır. Kentte üretilen somon ekmeğinin köydeki tandır ekmeğinden daha değerli olduğu düşünülmektedir. Beyaz ekmeğin (kepeksiz) esmer ekmekten (kepekli) üstün olduğu ve tercih edildiği görülmüştür. Bitkisel margarin yağlarının tereyağı ile başa baş değiş̧tirildiğini katılımcılar belirtmektedir. Bu durum 2000'li yılların başına kadar devam etmiştir. 2000'li yıllarda köyde üretimin bitme noktasına gelmesi ve tüketicilerin bilinçlenmesi ile birlikte köyde üretilen ürünlere büyük talepler oluşmaktadır. Patates, yağ, mısır, fasulye ve peynir fiyatları piyasa fiyatlarının olukça üzerinde seyretmektedir (K2, K3, K4, K7, K12, K8).

\section{Kentin Cazibesinin Yüksek Olması}

Modern dünyanın araçlarının birçoğu köydeki her eve girmiş bulunmaktadır. İkamet yerlerinin hemen hemen hepsinde telefon ve/veya televizyon bulunmaktadır. Aynı zamanda 20 yıl önce haftada bir kez ulaşabildikleri kent merkezlerine artık her zaman ulaşma imkânı bulunmaktadır. Bu durum on- 
ların daha fazla kentte kalma arzularını artırmaktadır. Kentte kalıp alışveriş yapmak, dinlenme yerlerinde vakit geçirmek, telefon ve televizyondan gördüğü yaşama ulaşmak arzu ettikleri bir durum olarak karşımıza çıkmaktadır. Diğer yandan ketteki evlerin ısınma sistemlerinin pratikliği, asansör sistemleri, hastaneye olan yakınlık, çocukların eğitimi de önemli bir etken olmaktadır (K18, K21, K22, K19, K25).

\section{Kent Hayatının Zorlukları ve Destekler}

Anne babası köyde yaşamış kişilerin kentte yaşaması bir nebze zorluk barındırmaktadır. Ancak kişi gelenek olduğu üzere köyünde yaşayıp sonra kente göç etmişse bu zorluk oranı oldukça yüksek görünmektedir. Çünkü bir yandan yer değiştirmenin zorluğu diğer yandan kente uyum sağlama zorluğu bir arada bulunmaktadır. Bu iki zorlukla baş edebilmek için göçmenler bir hayli yorulmaktadırlar. Bunların ötesinde bir üçüncü zorluk karşılarına çıkmaktadır. Bu da gelenekten modernliğe göçtür ki bu göçün kişilere etkisi diğerleri ile kıyas edilemeyecek kadar büyüktür.

Evlenebilmek için kente göç etmek zorunda kalan erkekler de kent hayatına katılabilmeyi oldukça önemsemektedirler. Göç edebilmek için ellerinden gelen birçok şeyi yapmaktadırlar.

Göç etmekle sorunlar çözülmüş olmamakta aksine yeni sorunlarla karşılaşmanın yolları açılmış olmaktadır. Evlenmek için göç eden erkeklerin kentte yaşadığı en önemli sorunlar; kentten iş bulma, işe uyum sağlama, beslenme, barınma, çevre edinme ve kente uyum sağlamadır.

\section{İş Bulma ve İşe Uyum}

Göç eden genç erkeklerin yaşadığı en önemli sorun iş bulmaktır. İş bulmak için çok yoğun çaba gerektirdiğinden yakın çevrelerinden yardım almaktadırlar. Akrabaları, hemşerileri veya arkadaşları aracılığı ile kentte düşük ücretli işler bulabilmektedirler. Bulabildikleri işlerin başında apartman görevliliği, garsonluk ve inşaat işçiliği gelmektedir. Kentte bir süre kaldıktan sonra gerek çevresinin yardımı ile gerekse tecrübesi ile daha yüksek ücretli ve daha az yorucu işler bulabilmektedirler. Bazıları ise hafta sonlarını da değerlendirip köyde ek iş yaparak gelirlerini artırma yoluna gitmektedir. 
Kentte bulduğu iş, köydeki geleneksel işten oldukça farklıdır. Bunun nedeni ücretli olması ve başında bir yöneticisinin bulunmasıdır. Yöneticinin talimatlarına sürekli uymak zorundadır. İstediği şekilde dinlenme, ara verme, iş planı yapma olanağına sahip değildir. Geleneksel köy hayatında, pazarda sattığı sebze-meyve, hayvan, süt mamullerinden kazancını elde ederken, şimdi bu tür ürünlerinin hepsini hazır olarak almaktadır. Kazancı ise artık sadece sabit ücretidir ve ona bağlı olarak yaşamaktadır.

Tablo 3

Köy ve kent yaşamı arasındaki farklılıklar

\begin{tabular}{ll}
\hline Köydeki Yaşam & Kentteki Yaşam \\
\hline $\begin{array}{l}\text { Geleneksel aile yönetimi ile üretim } \\
\text { Geleneksel yöntemle ürettiği ürünü satarak kazanç } \\
\text { elde etme }\end{array}$ & $\begin{array}{l}\text { Modern işletme yönetimi iler üretim } \\
\text { Kendi evi }\end{array}$ \\
$\begin{array}{l}\text { Müstakil ev } \\
\text { İs planını kendisi yapması }\end{array}$ & Apartman dairesi \\
Doğa şartlarından büyük oranda etkilenme & İş planının işletme tarafından yapılması \\
Çalışma saatlerinin güneşe, yağışa ve mevsime & Doğa şartlarından az etkilenme \\
göre değişmesi & Çalışma saatlerinin her dönem aynı olması \\
Bedenen çalışmanın yoğun olması & \\
Farklı işlerin yapıılması & Bedenen çalışmanın azlığı \\
Kendi ürettiğini tüketme & Aynı işi yapma \\
Kendi kendine yeterlilik & Üretmediği ürünü tüketme \\
İkamete bağlı arkadaşlık & Bağımlılık \\
\hline
\end{tabular}

Gerek yukarıdaki tabloda verilen iş süreci ve kazanç ile ilgili farklılıklar gerekse yaşamın tümünü kapsayan farklılıklar göç edenlerde önemli değişime neden olmaktadır. Göç edenlerin bu değişime uyum sağlamaları oldukça uzun zaman almaktadir.

\section{Barınma}

İş bulduktan sonra ev kiralaması diğer önemli bir sorun olarak kişilerin karşısına çıkmaktadır. Kişiler genelde, bekâr oldukları zaman, bir araya gelerek kirası düşük evlerde kalmaktadırlar. Bazen de tek başına ev tutup ailenin diğer üyeleriyle beraber kalmaktadırlar. Genç erkek evlendiği zaman, önceki kaldığ 1 eve göre kısmen kirası yüksek olan daha geniş ve konforlu bir eve taşınmaktadır. Çünkü evlenecek olan kız ondan daha konforlu bir ev tutmasını beklemektedir (K19, K11, K22, K25, K9). 
Nişanlı kızların genelde yakın çevresinden duyduğu en önemli tembih şunları içermektedir; kızın rahat edebileceği konforlu bir evin kiralanması ya da satın alınması, çevresine göre iyi sayılabilecek düzeyde ev eşyası alması ve düğünün güzel şekilde yapılmasıdır. Bunlar; yeni kente taşınmış ve yeni iş bulmuş erkek için büyük zorluklar demektir. Yukarda bahsedilen üç önemli şartı yerine getiren erkek bu ödeme yükünden ancak 5 ile 10 sene arasında kurtulabilmektedir. Sonraki dönemde ise, çocukların büyümesi ile bu yük artarak devam etmektedir (K18, K11, K20, K24).

\section{Beslenme}

Diğer bir sorun ise beslenme zorluğudur. Çünkü göç edenlerin almış oldukları düşük ücret, yüksek olan kira, ulaşım ve düğün masraflarının ödemelerine gitmektedir. Bu yüzden göç edenler, çoğu kez yeme-içmelerinde kısıntıya giderek çözüm yolu bulabilmektedir. Gençler, bu meseleyi çözebilmek için genelde köydeki tarlada üretim yapmaktadır ya da anne-babasından gıda yardimı almaktadırlar. (K12, K13, K22, K25).

Yakın kente göç edenler haftalık izinlerini köylerine giderek geçirmektedirler. Bir yandan akraba ziyareti yaparak sosyal ihtiyaçlarını karşılarken diğer yandan da en çok para kazanacakları ya da kışın tüketecekleri sebzeleri yetiştirmektedirler. Ücretlerin düşük olması onları ek iş bulmaya itmektedir ve kentte ek iş bulmak oldukça güçtür. Bundan dolayı köyde yapabilecekleri işleri yaparak ek gelir elde ederler (K5, K8, K18, K22).

\section{Kente Uyum Sağlama ve Çevre Edinme}

Köyde geçirilen sürelerde oluşturulan sosyal çevre ile kentte oluşturulan sosyal çevre birbirinden farkl11ıklar göstermektedir. İlk göç edenlerin genelde sosyal çevresi hemşerileri ve akrabalarından oluşmaktadır. Kentte kaldıkça sosyal çevre değişmektedir. Kişinin kentteki yaşamında, sivil toplum kuruluşları üyeleri, iş arkadaşları, okul arkadaşları, asker arkadaşları vb. zamanla hemşeri ve akrabaların yerini almaktadır. Biryandan birey olarak kendini oluştururken bir yandan da çevresini sürekli geliştirmektedir.

İşten çıkarılma riski, daha iyi çalışma ortamı oluşturma ihtiyacı, geçimini sağlama çabaları kişilerin içine kapanık olmasının önünde önemli bir sınırdır. $\mathrm{Bu}$ sınır sayesinde kişi dışa dönük olmak zorundadır. Ancak kadınlarda bu 
durum ters olarak işlemektedir. Kadının kentte çalışma hayatına katılamaması, sürekli evde vakit geçirmesi onu yalnızlığa ve içe kapanmaya ittiği görülmektedir. Kadınlar, bu meseleyi, hafta izinlerinde köye giderek ve çalışma günlerinde akrabalarına uğrayarak kısmen çözebilmektedir.

\section{Sonuç}

Zamanın ihtiyaçlarına ve ruhuna göre göçler de evrim geçirmektedir. 1950'li, 1970'li, 1980'li, 1990'lı ve 2000'li yılların göç biçimleri farklılıklar göstermektedir. Cumhuriyet'in kuruluş yı1ları, bu bölgede yoksulluk yılları olarak değerlendirilebilir. O dönemde göç yok denecek kadar azdır. Köylülerin, kentlere göç etmesini sağlayacak sermaye ve ağ ilişkisi bulunmamaktadır. 1950’li yıllarda gurbete gitme başlamış ve bu durum 1980'li yıllara kadar devam etmiştir. Kazanılan para köye getirilip köyde büyük ailenin ihtiyaçları için harcanmaktadır. Sonraki süreçte ise süresiz aile göçleri başlamıştır. Aile göçleri köylerin gerçek anlamda nüfusunun azalmasına sebebiyet vermiştir. Çünkü artık göç eden geri gelmemektedir.

Kırdan kente göçler artık tamamlanmak üzerdir. Geleneksel köy kültürünü önemli ölçüde yaşayan son genç nesil, kente göç etmekte ve böylece geleneksel kültür önemli bir dayanağını kaybetmektedir. Artık geleneksel yaşam usulü yerini modern usule bırakmaktadır. Emekli olanlar köylere gelip belirli mevsimlerde köyde yaşamaktadırlar. Bunlara hafta sonu gelip kalanlar da eklenince köylerin eskisinden daha fazla dolacağı söylenebilir. Özellikle ana yola ve kent merkezlerine yakın köyler önem kazanmaktadır ki bu köylerdeki gayrimenkul satış fiyatlarının yüksekliği bunu göstermektedir.

Son dönemde, birçok genç erkek köyde ikamet ettiği için evlenememektedir. Evlenemediği için kendini kente göç etmeye mecbur hissetmektedir. Kadınlar bu yolla hem erkekleri kentli olmaya zorlarken hem de kendileri kentli olmak için iyi bir fırsat oluşturmaktadırlar. Kendi olanaklarını kendileri oluşturarak modernleşmeye adım atmaktadırlar. Göç ve evlilik süreci sorunlarla dolu olsa da geleneksel yaşamda karşılaştıkları sorunlardan daha kolay görünmektedir. Bu da göç kararı vermede önemli bir etken olarak görülebilir.

Kızların köyde yaşayan erkekleri eş olarak tercih etmemelerinin önemli sebepleri bulunmaktadır. Bunlardan birincisi, büyük aile kurumunun kısmen 
devam etmesidir. Köyde yaşayanların haneleri her gün kalabalık olmasa da önemli günlerde veya hafta sonlarında yoğun olma ihtimalleri bulunmaktadır. Bu durumda gelinin görevi geleneğe göre hizmet etmektir ve bu durumu kızların büyük çoğunluğu kabul etmemektedir. İkincisi, gözetlenmenin bazı kişileri rahatsız etmesidir. Evler az katlıdır ve insanlar kolaylıkla diğerinin ne yaptığını görebilir veya tahmin edebilir. Görülen her farklı davranışı komşusu, köylüsü ve hatta ailesi yadırgamaktadır. Bu durum kişileri sürekli kontrol ediliyormuş hissi vermektedir. Üçüncüsü, tarlada, ahırda ve evde çalışmak zorunda kalma ihtimalidir. Belirtilen her üç konumda da ayrı ayrı işleri bulunmaktadır. Dördüncüsü, kentte yaşamak köyde yaşamaktan ve kentteki meslekler köydekilerden daha itibarlı olarak görülmektedir. Beşincisi ise kent hayatının çok daha cazip gelmesidir.

Köyden göç edenlerin kentte karşılaştıkları sorunlar azımsanmayacak kadar çoktur. Bunlar: sürekli aynı işin yapılması, iş planının başkası tarafından yapılması, birisinin emrinde çalışmanın zorunluluğu, çalışma yaşamında esnekliğin az olması, kira ödenmesi, gıda ürünlerine önemli oranda harcama yapma zorunluluğu, çocukların oyun sahalarının kısıtlı olması, kadınların üretime katılmalarındaki güçlükler ve komşuluk ilişkilerinin değişmesidir.

Köyde yaşayan 50 yaş ve üzeri kadınların kendilerini bahtsız olarak gördükleri tespit edilmiştir. Hem geleneksel yaşamın zorluğunu (büyük aile içerisinde gelinin diğer üyelere göre fazla çalışması) çekmiştir hem de modern yaşamdaki yaşlı bireylerin itibarsızlığı ve yalnızlığını yaşamaktadırlar. $\mathrm{Bu}$ kişiler genç yaşlarında kaynanalarına gelinlik yapmış ve yaşlanınca da gelinlerinden fayda görememişlerdir.

Modernliğe direnenlerin sayısı köylerde birkaç aileyi geçmemektedir. Onların yaşı da bir hayli ilerlemiştir. Baba ocağını tüttürebilmek, yani açık tutabilmek için çok çaba sarf etmektedirler. Bazen bu kişiler sırf evin kapanmaması için çocuklarından ayrı olarak yalnız yaşayıp kente göç etmemektedirler.

Göç eden genç erkeklerin neredeyse tümü evlenmişlerdir. Kentlerde yuvalarını çekirdek aile biçiminde kurmuşlardır. Geniş aile yapısı yok olmak üzeredir. Diğer yandan köyde yaşamını devam ettiren gençlerin sayısı oldukça düşmüştür. Onların da akranları gibi göç edeceği tahmin edilmektedir. 


\section{Kaynakça/References}

Abadan-Unat, N. (2006). Bitmeyen Göç: Konuk İşçilikten Ulus-Ötesi Yurttaşlı̆̆a (2. Bask1). İstanbul: Bilgi Üniversitesi Yayınları.

Başel, H. (2007). Türkiye' de Nüfus Hareketlerinin ve İç Göçün Nedenleri. Sosyal Siyaset Konferansları Dergisi, 53, 515-542.

Castles, S., Miller. M. J. (2008). Göçler Çăğ: Modern Dünyada Uluslararası Göç Hareketleri, İstanbul Bilgi Üniversitesi Yayınları.

Çağlayan, S. (2006). Göç kuramları göç ve göçmen ilişkisi. Muğla Üniversitesi Sosyal Bilimler Enstitüsü Dergisi, Güz Dönemi, 17.

Çelik, F. (2005). İçgöçler: teorik bir analiz. Ç.Ü. Sosyal Bilimler Enstitüsü Dergisi, 14(2), 167-184.

Çelik, N. (2012). Türkiye'de Göç Veren İllerde Iç Göç Sorununun Yönetiminde Stratejik Planlama Modeli Yapılandırılması, Doktora Tezi, Bülent Ecevit Üniversitesi, Sosyal Bilimler Enstitüsü.

Gemalmaz, E. (1995). Erzurum İli A ğızları, Türk Dil Kurumu Yayınları: 590.

Gezgin, M. F. (1991). İşgücü Göçü Teorileri, Sosyoloji Konferansları Dergisi, 23, İstanbul Üniversitesi.

Hocaoğlu, B. (2011). Bulgaristan'dan Türkiye’ye Yönelik Göçler ve Göçmen Yerleşme Alanlarında Sosyo - Ekonomik ve Mekânsal Özellikler. Doktora Tezi, Ege Üniversitesi Sosyal Bilimler Enstitüsü.

Kara, M. (2013). Tasavvuf ve Tarikatlar Tarihi. İstanbul: Dergah Yayınları

Karpat, K. H. (2010). Osmanlı Nüfusu 1830-1914. İstanbul: Timaş Yayınları.

Özgür, E. M. ve Aydın, O. (2011). Türkiye'de evlilik göçünün mekânsal veri analizi teknikleriyle değerlendirilmesi. Coğrafi Bilimler Dergisi, 9(1), 29-40.

Şencan, M. N. (2013). Türkiye ’ye Göç Eden Bulgaristan Türkü Kadınların Göç Hikâyeleri, Doktora Tezi, Yeditepe Üniversitesi, Sosyal Bilimler Enstitüsü.

TDK,http://www.tdk.gov.tr/index.php?option=com_gts\&arama=gts\&guid=TDK. GTS.5b4b0efb5ee866.80914460, Erişim Tarihi: 05, 06, 2018.

Tureng, İngilizce sözlük http://tureng.com/tr/turkce-ingilizce/homeless, Erişim Tarihi: $05,06,2018$.

TÜİK, ADNKS, https://biruni.tuik.gov.tr/medas/?kn=95\&locale=tr, Erişim Tarihi: 01.10.2018.

Vergin, N. (2010). Siyasetin Sosyolojisi; Kavramlar, Tanımlar ve Yaklaşımlar, Doğan Kitap, 7. Bask1, İstanbul.

Yılmaz, C. (2009). Türkiye'de kırdan kente göç sürecinde etkili olan faktörlerden biri; Evlilik yoluyla göç. Doğu Coğrafya Dergisi, 21, 221-232. 